Title: A is for Advocacy Author: K.E. Hones

\title{
$A$ is for ADVOCACY \\ School Library Networks: \\ Influencing education policy and reform
}

\author{
K.E. Hones \\ School Librarian \\ Stevenson School, San Francisco, CA \\ U.S. A.
}

A is for Advocacy provides a framework for library media teachers to consider the local opportunities they have to influence educational policy and reform. Library media teachers can build on personal strengths find opportunities at hand and capitalize on connections. Four main ideas will be developed: the message they want to spread, the mode in which they want to work, the means by which they can influence others, and how to build momentum to carry through their work.

The variety of avenues to influence educational policy and reform includes local site-based reform, teacher action research, networking, and publication. Through an interactive dialogue, school library teachers will develop a framework for advancing their influence and advocacy work. Through a reflective dialogue on their current practice, participants can develop a vision for action and the means by which they can make pro-active decisions about how to move their advocacy forward.

\section{Policy and Teacher Action Research}

“...Implementation problems should be considered when policies are made. Better policies would result, we are told, if policy makers would think about whether their decisions could be implemented before they settle on a course of action.” Richard F. Elmore

"Each stage in the policy cycle offers opportunities for research to inform the process. Understanding which stage your research can inform will help you determine your target audience. Understanding which stage you want to influence will help you design applicable research.” Sheldon Gen, San Francisco State University

\section{References}

Elmore, Richard F. (1980) "Backward mapping: implementation research and policy decisions.” Political Science Quarterly, Vol. 94, No. 4 (Winter 1979-1980) 
Gen, Sheldon (2004) "Influencing the policy process.” Presentation by professor in the Public Administration Program, San Francisco State University sgen@sfsu.edu

Hirsch, Eric (2005) “Teacher working conditions.” Presentation of findings from Center for Teaching Quality http://www.teachingquality.org/

Meyers, Ellen and Frances Rust. (2003) Taking Action with Teacher Research. Portsmouth, NH: Heinemann ISBN: 0325005443

Hubbard, Ruth S. and Brenda Miller. Power (2003) The Art of Classroom Inquiry. Portsmouth, NH:Heinemann; Revised edition ISBN: 0325005435

Carnegie Foundation for the Advancement of Teaching

http://www.carnegiefoundation.org/index.asp

Carnegie Perspectives online at

http://www.carnegiefoundation.org/perspectives/

NBPTS Certificate:Library Media

http://www.nbpts.org/candidates/guide/whichcert/24EarlyChildYoungLibMedia2004.html

\section{Author Note:}

K.E. Hones is a National Board Credentialed Library Media teacher and a support provider at Stanford and San Francisco School District for National Board candidate teachers. She has served on school site councils, advocating for and voting on decisions that impact quality teaching and learning. She is the co-chair of the San Francisco School Librarian Association facilitating professional development for district school librarians and working with union to establish school library job description, contract issues and evaluations. Currently a member of two textbook adoption committees 2006-07 (History/Social Science \& Health), she also participated on standards committees, content master plans and developing exemplar lessons. She has created and delivered professional development for $20+$ years, including for district, state, national \& international audiences. 
Reproduced with permission of the copyright owner. Further reproduction prohibited without permission. 